\title{
Entrevista com bordadeiras do Morro São Bento de Santos: uma reminiscência dos bordados da Ilha da Madeira
}

\author{
Vivian Pisaneschi Cruz \\ Instituto de Psicologia da Universidade de São Paulo
}

\begin{abstract}
idéia de entrevistar as bordadeiras do Morro São Bento (município de Santos, São Paulo) partiu da constatação de que há determinados tipos de trabalho que perderam seu espaço na sociedade atual. A costureira, o alfaiate, o sapateiro ${ }^{2}$ - que moldavam e confeccionavam, artesanalmente e sob medida, as vestimentas e os calçados para os estratos médios da sociedade - começaram a perder seu espaço para as grandes indústrias. Atualmente, alguns desses profissionais têm seu espaço de trabalho restrito a fazer pequenos consertos de artigos industrializados, isto é, apenas fazem reformas.
\end{abstract}

O intuito da entrevista foi o de registrar o trabalho artesanal, conhecer um pouco sobre seu aprendizado, saber os caminhos possíveis de geração de renda, bem como a sua relação com a arte. Ainda, buscou-se conhecer o ponto de vista das pessoas que realizam esse trabalho.

Dentre a diversidade de profissões que parecem não ter o mesmo espaço já experimentado outrora, a escolha de bordadeiras deu-se por um interesse pessoal.

Para contatar as bordadeiras, a primeira busca deu-se pela internet, que me conduziu à Secretaria da Cultura de Santos. Esse órgão me indicou um grupo de bordadeiras que expunha seus trabalhos em determinados pontos da cidade. Foram dois os encontros com as bordadeiras do Morro São Bento.

Foi assim que conheci dona Tereza Gonçalves Pestana, 70 anos, dona Maria Alexandre Fernandes, 73, dona Isabel Paixão, 78, e dona Maria Paixão de Abreu, 76, todas viúvas, bordadeiras que têm suas origens na Ilha da Madeira ${ }^{3}$ e que tiveram durante a vida toda o bordado como profissão. Elas se organizam em torno de um grupo que forma uma unidade, unidade essa que intenta a perpetuação do bordado da Ilha da Madeira. Elas expõem o trabalho em todo primeiro domingo do mês no Ilha Porchat Clube, em São Vicente (cidade conurbada a Santos) e em todo segundo domingo do mês no Orquidário Municipal de Santos. O primeiro encontro que tivemos deu-se no Ilha Porchat Clube e o segundo, durante o qual foi realizada a entrevista (importante dizer que o local da entrevista foi indicado por elas, como também partiu delas a solicitação de estarem juntas durante sua realização), no Orquidário.

Passei uma tarde inteira de domingo junto delas, no estande em que expõem seus bordados. A entrevista foi em grupo e perpassada por muitas pausas e interrupções, já que a todo momento aproximavam-se pessoas para ver o trabalho, comprar, fazer perguntas ou somente conversar com as bordadeiras. Essas pausas, entretanto, não marcaram a entrevista de forma negativa. Ao contrário, eram preenchidas com a possibilidade de observar e conhecer como elas se relacionam com o trabalho no dia-a-dia, como apresentam e explicam o bordado aos interessados e, além disso, como se relacionam entre si.

1 Trabalho realizado como parte das atividades da disciplina "Prática de Pesquisa em Psicologia Social I" do curso de graduação em psicologia, ministrada por Leny Sato no segundo semestre de 2006, no Instituto de Psicologia da Universidade de São Paulo. Agradecemos a Tatiana Freitas Stockler das Neves e Valéria Pisaneschi Cruz pelas sugestões que aprimoraram este trabalho. Contato: vivianneschi@yahoo.com.br

2 É bem verdade que atualmente, com a indústria da moda, esses profissionais têm experimentado a ampliação do espaço de trabalho, bem como a mudança do significado do trabalho em termos de visibilidade e de valorização social.

3 Dona Tereza, dona Isabel e dona Paixão nasceram na Ilha da Madeira e imigraram para o Brasil. Dona Maria é brasileira, porém filha de imigrantes madeirenses. 
O bordado, para essas senhoras, ultrapassa a esfera do trabalho e atinge as esferas da arte, da tradição e dos valores sociais. A profissão de bordadeira traz para elas uma grande identificação no que concerne à tradição ${ }^{4}$, sendo bastante arraigada a identidade portuguesa que o trabalho encerra. Também se pode verificar como trabalho e arte estão imbricados, ou seja, artista e artífice são uma só pessoa; cada peça produzida imanta o senso de utilidade e o senso estético. Isso aparece quando falam da beleza do bordado, da dificuldade em aprender e de todo o processo de trabalho.

Para as bordadeiras do Morro São Bento, o bordado canaliza a possibilidade de manter e ampliar os espaços de sociabilidade: como um grupo, elas estão em relação constante entre si; além disso, redes de relações são ampliadas nas ocasiões em que expõem seus trabalhos, tanto no que concerne a contatos profissionais, como pessoais.

Com isso, não é difícil entender o sentido que o bordado tem em suas vidas, ilustrado aqui pela fala de dona Tereza - "pra mim o bordado é tudo".

\section{“...a gente ia olhando e ia aprendendo...”}

Vivian - Eu queria que vocês contassem como é que vocês aprenderam a bordar. Vocês eram meninas? Como vocês aprenderam?

Isabel - Nós éramos pequenas (...). A mãe ensinou a gente. Primeiro bordamos... depois outro pontinho, depois a mãe ensinou as bolinhas, depois ensinou o cheinho, depois ensinou o caseadinho, foi ensinando. Nossa mãe foi ensinando e a gente foi aprendendo. Depois eu bordei letras, aquelas letras assim de gravar o nome, uma dúzia de letras, como é que se diz? Uma, outro dia era outro, fomos bordando esse (...) aqueles cabritos, aqueles cabritinhos de pano, ele punha assim na cortina e bordava.

Vivian - E quantos anos você tinha?

Isabel - Eu? Tinha já uns doze anos... treze pra quatorze anos e fomos andando e aprendendo a bordar tudo. Fizemos tudo...

Vivian - Aprendeu tudo de uma vez?

Isabel - Tudo, fomos aprendendo até bordar. Mas o que eu bordava mais era letra mesmo, aquela dúzia de letra. E depois a minha mãe que usava aqueles sacos caseados, aqueles que ficavam virados, aqueles... fronha, lá a gente chamava saco e a minha mãe bordava aquele saco, caseava em volta, era pra pôr na cama.

Maria - Agora é a minha vez?!

Vivian - Pode ser.

Maria - Eu sou Maria Alexandre, eu bordo desde pequenininha, com sete anos, ou até menos. Eu estava pertinho da minha mãe, aprendendo com ela e o que eu sei fazer hoje é graças a ela, faço de tudo um pouquinho. Português, tipo português mesmo, né! E adoro muito andar com minhas colegas, me chamaram porque sou brasi... eu sou a única brasileira, elas são portuguesas. Então, eu entrei no grupo e estou até hoje com elas, e graças a Deus, estou muito satisfeita, gosto, adoro, quando é o tempo da gente ir lá pro Ilha Porchat ${ }^{5}$ expor nosso bordado ou então aqui no Orquidário ${ }^{6}$, gosto mesmo, das minhas amigas, do meu trabalho, gosto muito daquilo que eu faço. Faço mais roupinha de criança, porque eu comecei fazendo bordado pra fábrica em São Paulo. Eu ia fazendo (...) bolinhas, fazia caseado com a minha mãe, pontinho de haste e estes pontos mais fáceis. Ela então ia fazendo o

4 Tradição é o termo usado pelas próprias bordadeiras refere-se não a algo estático, mas a algo vivo, ou seja, à história e à cultura. Vivo na medida em que, ao mesmo tempo em que a prática do bordado reproduz-se ao longo dos tempos, também se altera no movimento do próprio bordar.

5 O Ilha Porchat Clube situa-se na cidade de São Vicente, que é cidade conurbada a Santos. Fica na Ilha Porchat, área nobre da cidade. Todo primeiro domingo de cada mês as bordadeiras expõem seus trabalhos no clube.

6 O Orquidário Municipal de Santos abriga várias espécies de orquídeas e de animais silvestres. Todo segundo domingo de cada mês as bordadeiras expõem seus trabalhos ali. 
cheio, o trigo, pra ela mandar pra São Paulo e era assim e foi aí que eu comecei e tô até hoje e vou continuar muito se Deus quiser, até eu enxergar, muito, muito!

Tereza - A história é tudo a mesma.

Paixão - Eu comecei com cinco, seis anos e já bordava, e minha mãe a gente ia olhando e ia aprendendo e até hoje (...)... não tinha professora pra ensinar, não tinha, a gente ia olhando e já ia fazendo...

Isabel - E a senhora quer melhor professora que a sua mãe?

Paixão - Com cinco anos já ia fazendo (...) e era assim e assim foi indo.

Tereza - Eu também, a mesma história. Eu sou a Tereza e comecei a bordar também de menina e a gente vai vendo como a nossa mãe faz, as irmãs e então a gente vai entrando no ritmo e vai fazendo, e continuei fazendo. Vim aqui pro Brasil e cheguei aqui aí, já tinha bordado pra eu bordar e vai continuando até hoje e a minha profissão cada vez eu gosto mais, eu gosto (...), continuo trabalhando até hoje, se Deus quiser mais uns aninhos pelo menos.

\section{Imigração e primeiros tempos no Brasil}

Tereza - ...ficava lembrando, quando a gente bordava com a mãe, com as irmãs, que era tão gostoso, lá em Portugal, não era que nem aqui (...). Lá a gente se reunia assim: as irmãs, os vizinhos, que os vizinhos eram, que nem... moravam na minha rua, que era uma família, então, a gente se reunia bordando todas ali a tarde inteira, era tão gostoso e a gente já sabia que essa profissão era a nossa, não tem outra profissão, não tem nada estudado, então a gente foi continuando, bordando, bordando, bordando, aí quando eu vim aqui pro Brasil, quando eu cheguei, quando eu desembarquei aqui eu já tinha uma irmã e ela já tinha um jogo de lençol me esperando pra eu bordar e a minha lua-de-mel foi já trabalhando, porque ela já tinha um bordado pra eu bordar, não podia parar e esse trabalho a gente... o marido não foi de ganhar muito, então nós trabalhamos e ajudava muito nas despesas de casa (...).

Vivian - E como foi esse momento de imigração de vocês?

Tereza - Quando eu vim... eu casei e vim, meu marido tava aqui e eu vim, já me encontrei com ele aqui, a gente viveu enquanto deu. Infelizmente ele faleceu e eu continuo, com meu trabalho pra frente.

Vivian - Todas vocês são da Ilha da Madeira? Menos você, né, você é brasileira...

Tereza - Todas somos, somos bordadeiras da Ilha da Madeira mesmo.

Isabel - Menos ela que não é!

Maria - (...) ...mas todo mundo fala: "a senhora é portuguesa, sua família é toda portuguesa, o sangue é igual".

Vivian - Sua mãe também era da Ilha da Madeira?

Maria - Sim, meus tios, meus avós (...), eu sou a única brasileira, sou Maria Alexandre, como já falei.

Tereza - Ela é a brasileira, mas ela nasceu... ela é filha de portugueses e conviveu com português, porque nossa rua era só gente portuguesa, então ela é portuguesa.

Maria - Eu nasci e me criei aqui no Brasil, mas com minha família toda portuguesa, toda...

Vivian - Então a rua de vocês é toda de portugueses...

Tereza - Tudo proprietário português, então a nossa rua é sempre... (...) porque a minha rua é que nem uma família, considerava uma família, que desde a casa de Portuguesa até a casa de dona Beatriz ${ }^{7}$

7 Dona Beatriz Freitas Leão é uma figura muito importante para o grupo das bordadeiras e faleceu meses antes da entrevista. Mais adiante elas falam sobre isso. 
que era outra portuguesa, porque era que nem uma família, dona Maria pode falar a verdade, que é uma família, que é só gente que a gente conhece e a gente vai no portão, conversa com um, conversa com outro, é só... é uma família praticamente ali...

Isabel - Quando eu vim, eu vim de Portugal fui pro Marapé ${ }^{8}$, fiquei ali por quatro anos, depois meu marido mandou buscar o irmão, fomos lá pro morro, por isso que a gente mora no morro, fomos lá pro morro... senão até hoje a gente morava no Marapé, fizemos lá uma casa, com tanto sacrifício pra fazer, e moro até hoje, eu moro lá há cinqüenta anos...

\section{Os primeiros tempos do trabalho e freguesia}

Vivian - Como que vocês conseguiram a freguesia, como foi, vocês começaram com a mãe de vocês e já levaram isso como um trabalho ou não?

Isabel - Já, fazia pra fora... sempre pra fora, ganhar um dinheiro.

Tereza - Esse trabalho era nosso futuro!

Isabel - A gente fazia pra uma fábrica de São Paulo.

Paixão - Era pra São Paulo, aí depois que apareceu isso aí... ${ }^{9}$

Maria - Eu, quando deixei de bordar pra fábrica, com a minha mãe, porque eu ajudei muito a minha mãe, aí eu casei, depois que eu casei, comecei a fazer minhas coisinhas, por minha conta, minhas roupinhas de bebê, aí eu levava nas lojas na cidade, Casa Carlos, levava na Camisaria Estudante, levava ali na São Leopoldo, aí eu comecei a vender pras lojas, só que eles pagavam muito pouquinho, então a gente tinha que comprar o pano, tinha que bordar, já dava prontinho, embaladinho pra eles, quer dizer que eles é que iam ganhar e eu ganhava muito pouquinho e com o pouquinho que eu ganhava já me ajudava muito porque o meu esposo estava desempregado e aí era uma coisa que me ajudava muito pra levar pra feira, no mercado, pras minhas crianças, porque eu tinha minhas crianças pequenas, então me ajudou muito o meu bordado. Bendita hora que eu aprendi com a minha mãe, porque eu consegui fazer uma coisinha pra ganhar um trocadinho! Era pouco, mas sempre, graças a Deus, sempre trabalhei com o meu dinheirinho, sempre, muito pouquinho, mas é... mas depois, como eu estava falando, aí era a Tereza quem me levava o meu trabalhinho quando eu levava pras lojas também, mas a Tereza começou a fazer as exposições e levava uma coisinha pra mim, ela que vendia pra mim, levava. Vendia e chegava toda contente: "Maria, ó, eu vendi!"...

Tereza - Eu chegava e: “ô, amiga!”.

Maria - Eu tive muita sorte com as Terezas, porque eu tenho uma amiga também que é Tereza, que trabalhou na Sabesp há muitos anos atrás (...). Ela também levava muitos lencinhos, chegava o tempo das professoras, assim, em outubro, ela levava de dúzia que eu fazia pra vender pra mim lá na Sabesp, que ela trabalhava na Sabesp. Tinha as amiguinhas dela lá e então ela vendia pra mim, mas esta Tereza também vendia (...) porque meu esposo não deixava eu acompanhar elas, ele tinha muito ciúmes, ele não deixava eu vim na exposição, não deixava de jeito nenhum. Depois ele faleceu e nisso que ele faleceu, elas me convidaram a entrar, me convidaram, aí eu vim, com um pouco de vergonha, né, porque logo que ele faleceu eu vim, todo mundo falava "ai, a Dona Maria, o marido não deixava ela ir e agora ela tá indo”, mas aí eu de cabeça erguida passava com o meu trabalhinho e vinha acompanhando elas, pra todo lado eu ia com elas, quando tinha assim eventos, faculdade, entrevista, tudo eu acompanhei, tudo, tudo, nunca... só faltei só uma vez ou duas (...), não gosto de faltar, enquanto eu puder, que Deus me der vida e saúde, eu acompanho elas. Agora, quando eu ficar doentinha, paciência, aí eu vou pendurar a chuteira, como dizem...

Tereza - Ah, doença já são outros quinhentos! (...).

Vivian - E vocês, dona Paixão e dona Isabel, como vocês conseguiram a freguesia?

8 Bairro de Santos que fica próximo ao Morro São Bento, onde reside atualmente.

9 Refere-se ao grupo das bordadeiras. 
Paixão - A mesma coisa que elas estão falando, a gente bordava lá pra São Paulo, ficava em São Paulo e levava pra gente o bordado. Naquele tempo a gente bordava pra dar lucro pros outros, aí o seu Francisco $^{10}$ apareceu e já comprou pano, vai fazendo os bordados, eu não tinha nem dinheiro pra comprar.

Isabel - (...) ...ela [mulher responsável por levar o bordado para as fábricas em São Paulo] riscava o bordado e dava pra gente, quer dizer que ela ganhava mais que a gente. A gente bordava aquelas colchas grandes, aqueles lençóis grandes, deste tamanho que a Tereza borda, eu bordava naquele tempo. Era tudo pra São Paulo, era tudo pra elas venderem lá em São Paulo (...). Depois bordei particular, depois comecei a bordar, passei a bordar com nós e pronto, que já também não, às vezes meu marido vendia também algum jogo, no hotel, aí depois a dona Beatriz me convidou pra ir com ela e eu vim (...). Em Portugal a gente ajudava a mãe, porque eu fiquei nova sem pai, então, nós éramos obrigadas a trabalhar, minhas irmãs não queriam trabalhar na fazenda, a fazenda tinha bastante [trabalho] mas não quis trabalhar.

\section{"Vocês são as bordadeiras do morro!"}

Tereza - O grupo União das Bordadeiras do Morro São Bento ${ }^{11}$, porque era um senhor lá e ele foi reunindo as bordadeiras, chamando uma por uma e reunindo, e pra gente formar um grupo e cada uma fazendo o seu bordado e a gente sair pra vender, graças ao seu Francisco do Nascimento, um jornalista, e ele foi juntando as bordadeiras... e a gente sempre fala, graças ao seu Francisco que a gente tá aqui, aqui nesses bordados até hoje, muito bom.

Vivian - E foi assim que vocês se conheceram?

Tereza - Não, a gente já se conhecia, mas depois do bordado, aí que a gente pegou mais amizade e entre nós é assim uma amizade que nem uma família, eu e a dona Paixão, há tantos anos que a gente anda juntas e eu não tenho nada que falar dela e acho que ela também não tem nada que falar de $\operatorname{mim} . .$.

Maria - Eram muitas bordadeiras, depois ficaram em cinco, dona Beatriz, dona Tereza, dona Paixão, dona Isabel e eu. A dona Beatriz faleceu agora em maio, então, foi uma grande lutadora por este grupo, com a Tereza e a dona Paixão, no começo, foram as três que lutaram muito, por tudo quanto foi, pra ir p'rum lado, pro outro, era dona Beatriz, Tereza e dona Paixão... (...).

Vivian - E como é que foi que vocês chegaram? A dona Beatriz foi uma grande lutadora, mas...

Isabel - Foi sim, foi sim, foi sim.

Vivian - ...foi o seu Francisco...

Tereza - O seu Francisco que foi o nosso coordenador, ele subiu o morro, ele morava na cidade, subiu o morro, reuniu todas as bordadeiras, fazia reuniões que era, que era dar certo, que a gente tinha que pôr sempre na cabeça que ia dar certo. No começo, ninguém queria - né, dona Paixão? - ninguém queria andar com bordado, que não ia dar certo, que não vai dar certo. Aí um dia (...), eu e a dona Beatriz, a dona Paixão, nós nunca desistimos e as minhas filhas tinham: "mãe, a senhora não deixa de ir, a senhora não deixa de ir" e nós fomos. Fomos lutando, lutando, lutando. Nós sofremos um pouco nisso, a gente sofreu um pouco mas fomos lutando e o seu Francisco dando uma força pra gente: "vocês não desistam, não desistam". Agora, até hoje, depois quando a gente, que nem, eu sempre falava pra ele: "ó, seu Francisco, agora sabe que a gente já não precisa mais andar pela mãozinha, o senhor deixou a gente". Mas ele sempre acompanhou a gente nas exposições, onde a gente fosse, ele tava sempre orientando a gente: "é assim, é assado" nossa, olha, foi um professor muito grande pra nós!

Vivian - Mas foi ele que chegou em vocês ou vocês chegaram nele?

10 Francisco Ribeiro do Nascimento, jornalista que pesquisou os bordados madeirenses em Santos. Foi presidente da Casa do Folclore "Professor Albino Luiz Caldas".

11 No Morro São Bento, na cidade de Santos, residem muitos portugueses e descendentes. Todas moraram ali (somente dona Tereza não mora mais atualmente lá) e têm o Morro como ícone de seus bordados e de sua tradição. 
Tereza - Foi ele que chegou na gente.

Vivian - Vocês não imaginavam antes de formar um grupo...

Tereza - Não, nunca. Primeiro começou o seu Albino Caldas ${ }^{12}$, que era um professor do... Á, infelizmente, quando ele estava reunindo as bordadeiras pra fazer exposição, o seu Albino Caldas faleceu, o seu Francisco ficou no lugar do seu Albino... então, ele foi orientando a gente, no começo a gente não tinha nem dinheiro pra comprar o pano, eles compraram, as primeiras peças foram eles que deram o pano e a gente foi fazendo e vendendo e graças a Deus fomos indo, indo, indo, até hoje...

Maria - Então, graças a Deus, estão reconhecendo muito nosso trabalho.

Tereza - Mas depois de muitos anos que eles vieram dar valor às bordadeiras. Que a gente ia a um lado, a outro e ninguém conhecia a gente, ninguém sabia que a gente existia. E então a gente foi indo, foi indo, foi indo, com aquele anúncio da Tribuna ${ }^{13}$, as pessoas foram se achegando mais até nós, aí, graças a Deus, hoje a gente tem mais, uma audiência maior, qualquer coisa: "ai, vocês são as bordadeiras do morro!" (...).

Tereza - ...nós pastamos na vida, nós pastamos...

Vivian - Como assim vocês pastaram, o que aconteceu?

Tereza - Que o começo tudo é difícil, né!

Vivian - Então conta esse começo...

Tereza - E a gente vai num lugar, a gente não consegue lugar pra expor, vai num outro, eles também não conhecem a gente, também não dão muito apoio. E então o seu Francisco é que foi, por isso que a gente vai sempre no Ilha Porchat, porque o seu Francisco, acho que ele conheceu o doutor Odárcio ${ }^{14} \mathrm{e}$ conversando com ele levou a dona Beatriz e a dona Júlia ${ }^{15}$ pra irem lá e então, conversando, aí ele arrumou um lugar pra gente expor e até hoje...

Maria - E olha, se a gente quisesse, todo domingo ele manda ir pra lá...

Tereza - Mas foi difícil. No começo foi difícil e ninguém conhecia a gente, também não conhecia o trabalho e já tinha-se aquele receio, né! (...).

Maria - Embora alguma vez tenha... algum grupo sempre é assim, como gente que trabalha num escritório, trabalha junto, marido e mulher, que de vez em quando tem um desentendimentozinho, mas acaba logo, na mesma hora, não assim, uma palavrinha, uma coisinha, mas aquilo na mesma hora já tá tudo bem.

Tereza - A dona Beatriz sempre falava: "o que a gente conversa aqui é pra morrer aqui!" e sai daquilo sem mágoas e é verdade, né!

Maria - Problemas. A gente não leva problemas pra casa, nem pra ninguém, é aqui mesmo.

\section{Do anonimato ao reconhecimento}

Vivian - Como vocês se sentem, qual a diferença, em relação a antes não serem conhecidas? Vamos falar sobre isso...

Isabel - Nós somos sempre as mesmas...

Tereza - Um pouco de orgulho a gente tem....

Maria - Nós somos muito simples...

12 Albino Luiz Caldas era professor e estudioso do folclore da Baixada Santista.

13 O jornal "A Tribuna” tem grande circulação na Baixada Santista e veicula o diário oficial da cidade de Santos. O anúncio referido é um release publicado no diário oficial do jornal.

14 Odárcio Ducci, presidente do Ilha Porchat Clube.

15 Dona Maria Júlia Fernandes, já falecida, foi também uma bordadeira do grupo. 
Tereza - ...toda vez que a gente chega num lugar: "ai, te vi na televisão”, aí outro: "eu vi a senhora na televisão, que chique, que isso”... mas agora eu sou artista, eu virei artista!

Isabel - Pra mim a mesma coisa!

Maria - Nós somos muito simples. Quem vem nos conhece, as pessoas que nos conhecem sabem, nós somos pessoas muito simplesinhas, muito simples, nem faculdade não temos...

Isabel - Nem ler eu sei.

Tereza - Se você ler o livro ${ }^{16}$, a dona Beatriz falava, falava no livro e ela sempre falava mesmo: "a minha faculdade é a faculdade de vida”...

Maria - É claro!

Tereza - ...é, a gente que vai passando, passando, e ela teve uma faculdade muito grande, a vida dela não foi fácil não, e ela deu conta de tudo (...).

Maria - Nós somos uma atração aqui na cidade de Santos. Porque a gente põe a faixa lá, ali no Orquidário. Muita gente vem, vem pra ver, pra conhecer o trabalho, não pra comprar, porque hoje em dia tá muito difícil, sempre sai alguma coisa, né, não vamos dizer que não, mas é assim, lencinho que é mais barato (...), um lencinho, um babadorzinho (...), paninho de bandeja, umas coisinhas baratas, porque o lençol de casal (...), um lençol de cama é mais caro, não é todo mundo que pode comprar, então é mais difícil de sair um caminho de mesa também, mas às vezes chega um e leva... (...).

Vivian - E você falou que você é uma artista, quando você falou assim: “ah, antes ninguém me conhecia, agora sou uma artista!”...

Tereza - Porque o povo, quando, às vezes, quando a gente fica, a Globo é muito vista e a gente aparece, aí: “ah, te vi na televisão!”, aí eu: "agora a gente é chiquésima!” (...). É, depois que a gente aparece na televisão: "ai, vi a senhora na televisão!”, aí outro: "ai, eu te vi na televisão!", “ai, mas agora eu virei artista, agora eu sou artista da televisão!", “ah, mas você não borda mais?”, "bordo, mas eu sou artista e bordo!” (...).

Maria - ...eu, quando a gente precisa ir numa faculdade, num colégio, a Tereza liga pra gente, o grupinho se une, nós vamos, damos entrevistas lá pras meninas fazerem... pra fazerem matéria pra faculdade. Quando tem um outro evento qualquer, que a nossa coordenadora é a Tereza e ela é quem liga pra mim e eu transmito pra dona Isabel e pra dona Paixão, aí a gente se encontra todas, porque uma, ela mora aqui na cidade, nós três moramos lá no morro, então, eu ligo pra esta, ligo pra dona Paixão e a gente se encontra, quando é o dia de vim pra cá, a gente já tá sabendo, mas a carta, a Tereza vai levar a carta, quando ela não pode levar, eu levo sempre e é assim, a gente se... é unida, tem que ser unido, quem trabalhar junto tem que ser muito unido, não é verdade? Mas...

Tereza - Isso agora pra nós é mais de uma aventura, que a gente não vê a hora de chegar o dia de, de o primeiro dia, o primeiro domingo, o segundo domingo, pra gente ir. Nossa, a gente já acaba o bordado com a alegria toda...

Maria - Não importa o que venda, domingo passado foi o dia das eleições, foi dia da gente ir, tava combinado, saiu anúncio na Tribuna, fomos pro Ilha Porchat Clube. Não vendemos nada, mas compramos nosso lanchinho lá, fizemos o nosso lanche, fomos pra gastar dinheiro, mas não tem problema, a gente se diverte muito, conhece muita gente, é uma alegria, a gente gosta muito daquilo que a gente faz.

Tereza - E a gente já tá acostumada com esse ritmo, então, se a gente tiver um domingo, por exemplo, tá um domingo de temporal que não dá pra gente sair, nossa, acho que a gente fica agoniada em casa.

Isabel - Mas sai com temporal no meio da chuva!

Maria - Hoje tava chovendo, hoje tava uma chuva, hoje de manhã tava chovendo, falei pra dona, aí falei pra dona Isabel - "vamos que o dia vai melhorar", chegamos aqui não é que deu sol? Deu sol... (...).

16 Refere-se à dissertação de mestrado de Gisela Kodja, intitulada "Bordadeiras do Morro São Bento: memória, trabalho e identidade”, concluída em 2004, na Pontifícia Universidade Católica de São Paulo. 
Tereza - O pessoal acha caro porque a gente vai falar o preço d'um jogo e d'uma toalha de lavabo o pessoal deixa na hora.

Isabel - É, cinqüenta reais... ninguém paga cinqüenta reais, eu vendi quarenta e cinco...

Vivian - Mas também não dá pra fazer por menos, né!

Tereza - Ah, não dá, não vendo, deixo pra vender no outro, mas por mim não dá... porque também trabalhar de graça não pode.

Vivian - Antes era diferente, antigamente era mais valorizado ou não?

Tereza - Sempre foi assim (...), sempre acharam o bordado feito a mão caro, mas é que é um trabalho muito demorado, então, não pode, uma toalhinha de bandeja não pode vender a dez reais.

Isabel - Eu vendo a trinta reais, a gente dá o pano, risca, dá a linha, quanto a gente ganha? Ganha muito não, né, Tereza? Ela sabe.

Tereza - Se fosse ganhar mesmo, se fosse ganhar um dinheirinho, era vender lenço, porque o lenço são as sobrinhas que sobram, então, que a gente corta um joguinho de berço ou de carrinho e sobra uma parte, que a gente faz um lencinho e vende por oito reais, dez, aí dá pra ganhar um dinheirinho, mas mesmo assim o povo acha muito caro um lencinho por oito, dez reais, acha um absurdo! (...) Mas nós somos teimosas. Não vende hoje, vende o mês que vem, não vende o mês que vem, vende o outro, mas vender, vende.

Isabel - Agora tá muito difícil!

Vivian - Agora mais que antes?

Tereza - Vende mais, agora se vende mais.

Vivian - Vende mais porque vocês são mais conhecidas?

Tereza - Somos mais conhecidas e vendemos. Quem vem pra comprar, o preço que tiver, paga. Quem conhece o nosso trabalho, se é pra comprar, se é duzentos paga duzentos, se é trezentos paga trezentos. Agora, quem vem só olhar, ou que não tá muito interessada acha caro e não compra, mas quem vem pra comprar, compra.

\section{"Ninguém quer a profissão de bordadeira"}

Vivian - Você conhece a origem da técnica do bordado? De onde vem isso?

Tereza - Não conheço, deve ser uma coisa muito antiga e a gente não sabe de onde vem, como começou e tudo. Não sei falar...

Vivian - Mas não é específico da Ilha da Madeira, é de Portugal em geral?

Tereza - É, de Portugal, mas os bordados da Ilha da Madeira sempre são os mais famosos (...). Mas quer dizer que é de Portugal todo, mas dizer como começou, assim eu não sei. As nossas mães e avós deviam saber mas não falaram pra gente, né, aí... (...).

Vivian - E a historinha do menininho e da menininha do lencinho, como é mesmo?

Tereza - Aquele bordado é típico da Ilha da Madeira, mesmo porque as moças se vestem com aquela roupa e ficam no cais vendendo flores pros turistas, porque vai muito turista da Inglaterra, dos Estados Unidos, vão na Ilha da Madeira e quando embarcam eles compram muitas flores pra levar e então as moças se vestem com esse traje e os moços também (...), toda vez que a gente vende tem que ficar explicando, porque eles não sabem o que aquilo significa.

Vivian - Então esta é bem característica da Ilha da Madeira?

Tereza - É, porque elas se vestem com esta roupa e ficam com a cesta de flores no braço.

Isabel - E tem algumas que ficam na cabeça, olha... 
Tereza - E vão vendendo flores, flores para os turistas...

Isabel - ...esta está pulando corda, esta já está vendendo o cestinho e tem outra que tá com o cestinho na mão.

Tereza - Este é o bordado característico da Ilha da Madeira.

Isabel - Este é! (...)

Isabel - Olha esta com o cestinho aqui!

Vivian - E os menininhos andam com o bordãozinho ${ }^{17}$ ?

Isabel - É, com o bordãozinho e a florzinha no cesto pra vender, não é dona Tereza?

Vivian - Entendi... (...).

Maria - ...já mais agora no final, já tá terminando a nossa tradição, tá acabando. Somos pouquíssimas agora, estamos agora em três: eu, dona Isabel e a Tereza, estamos dando aula no Teatro Municipal, aqui na Pinheiro Machado ${ }^{18}$, pra nossas aluninhas, que estão indo muito bem, pra ver se a nossa tradição não morre por aqui, continua e elas estão fazendo muito bonitinho. Agora em novembro já vai ter uma exposiçãozinha delas, nós estamos na maior alegria de ter passado alguma coisa pra elas, também aprendendo aquilo, passando da gente pra elas e pra nunca mais acabar e aí elas vão indo, vão indo... Vamos fazer o curso em três anos, que já falaram pra gente, pra elas se aperfeiçoarem bem, porque, no começo elas tão fazendo, tá bonitinho, tá ficando bonitinho, mas elas têm que se aperfeiçoar muito pra chegar como a gente faz, porque é um trabalho muito demorado. Este ponto de cheio da Ilha da Madeira é muito lindo, muito lindo, mas demora um pouquinho pra gente aprender, então tem que se aperfeiçoar bem, porque quanto mais a gente borda, mais vai aperfeiçoando o serviço.

Tereza - A gente ainda aprende... (...).

Vivian - E neste aspecto da tradição, que você tava falando, é muito importante isso. Vocês falaram que moram numa rua onde, numa colônia mesmo de portugueses e não tem mais pessoas além de vocês que façam este tipo de bordado, só vocês?

Tereza - Não, as mais velhas infelizmente já faleceram e as que tão, ninguém quer bordar, porque é um trabalho que é muito demorado e não dá muito lucro e as pessoas desistem, todo mundo desiste de bordar, então procuram trabalhar fora e o bordado, só pras pessoas mais velhas, mais idosas mesmo.

Vivian - E as filhas de vocês, os netos, eles não...

Isabel - Ninguém quer...

Tereza - Ninguém quer a profissão de bordadeira.

Vivian - Nem como profissão, mas como...

Isabel - ...sabem bordar...

Vivian - Sabem bordar...

Paixão - A minha filha borda, a mais velha, agora, a mais nova não.

Isabel - A minha filha borda, mas pra ela mesmo. Ela borda pra ela, para os netos... ela aprendeu num colégio de freiras, aprendeu tudo e minha neta, a Rita, sabe bordar, mas um pouco, porque ela não aprendeu muito, a mais velha. Agora, a do meio aprendeu a bordar com a dona Beatriz.

Paixão - Lá do lado dela!

Isabel - A dona Beatriz ensinou de graça e ela aprendeu (...).

Tereza - Agora, se levanta, se senta, levanta, senta, levanta pra fazer outra coisa, o bordado não fica bom, nem o nosso. Que a gente já tem a prática, se a gente tá bordando o telefone toca, senta e o telefone toca, olha, teve uma manhã essa semana que eu fiquei a manhã inteira no telefone, eu sentava, o telefone tocava, eu falei: "meu Deus, é hoje!". Aí senta, dá um ponto, pronto, vai atender,

17 Diminutivo de bordão, que significa cajado, bengala.

18 Avenida Pinheiro Machado, conhecida também como Canal 1. 
falei: "nossa!", o bordado não fica bom quando é assim. A gente tem que sentar ali sossegada, escutando, mais escutando que olhando, senão não fica um trabalho bom. Eu fiz essa toalhinha aqui... eu me sentei na areazinha de serviço, pus a cadeira de praia... aí eu me sentei lá sem televisão, sem nada, aí bordando assim, sossegada, aí é tão gostoso! Agora, o pessoal de hoje em dia não tem essa, ninguém quer ficar sozinha, sossegadinha num cantinho, por isso ninguém quer bordar, porque eu acho, eu acho não, pra mim, não sei se é pra todas, mas a gente sentar numa cadeira ou no sofá, porque eu gosto de bordar no sofá também, mas ficar ali sossegada, que é o serviço que rende e que fica bom (...). O nosso trabalho é assim, por isso que ninguém consegue... aí larga um pouquinho pra fazer almoço, aí deixa, aí guarda um pouquinho, larga pra fazer, aí não fica bom, não rende... tem que ser assim, tem que começar mesmo, de manhã é assim, eu, eu levanto, tomo meu cafezinho, então é sagrado... aí vou lá, faço meu cafezinho, tomo um pouquinho (...), aí pego e vou bordar, quando dá umas dez horas eu tomo um lanchinho, mas eu fico bordando, faço o serviço de manhã senão o bordado não rende, aí paro umas onze e meia pra fazer minha comidinha, adianto as coisas senão não borda. O bordado é assim, se começa a arrumar a casa e aí vou fazer este ponto agora, vou fazer este aqui, ai, minha filha, não borda nada.

Vivian - E à tarde você não borda?

Tereza - Bordo, faço o almoço e dou um jeitinho em minha cozinha, passo um pano pra não deixar muito sujo, né, aí dou um jeitinho na cozinha e passo a tarde bordando.

Vivian - Até de noite?

Tereza - Até de noite. À noite janto e continuo bordando até onze horas da noite, não, até dez e meia, dez, dez e meia...

Isabel - Eu bordo de manhã e bordo mais meio dia porque de noite eu não bordo não, bordo, mas quando eu bordava de noite, rendia mais que o dia...

Tereza - ...rende...

Isabel - ...isso é verdade!

Tereza - ...à noite a gente enchia este [ponto] cheio (...). Às vezes minhas filhas falam assim: "mãe, a senhora agora não precisa ficar bordando tanto", mas eu me ajeito, não sei ficar sem bordado, eu tenho que estar trabalhando.

Isabel - Quando eu bordava de noite, eu acho que rendia mais que o dia, eu sei, porque eu já bordei de noite, já bordei muito, pra gente que faz caseado, eu não sei, nada, nada...

Tereza - Quando a gente vem do teatro, aí eu falei assim, eu vou, aí eu comecei, alinhavei, passei a linha, aí comecei, vou ver se eu acerto a fazer daquele jeito. (...) $\mathrm{O}$ nosso grupo, às vezes eu fico meio preocupada, porque nós já somos idosas e vejo que fica uma doente daqui, uma doente dali e a gente se preocupa, com medo que acabe.

Vivian - Você tem medo que isso possa se perder...

Tereza - É, o medo de acabar assim, de uma hora pra outra, pode acabar, com isso fico muito preocupada mesmo.

Vivian - Por isso que você é "teimosa"?

Tereza - É, insisto, insisto e quando alguém liga e chama a gente para um lugar eu já falo que sim, eu já acerto e elas, eu sou a coordenadora e o que eu falar, quando eu concordar com uma coisa, vocês têm que ir, depois elas vão até chiando às vezes, porque a gente não pode dizer não pra ninguém, quando é uma faculdade, um colégio que convida a gente, eu falo: "pode deixar que a gente vai!" e a gente vai mesmo. Não pode acomodar, nosso grupo tem que ser forte (...), que quero que todo mundo tenha saúde pra poder trabalhar e peço sempre a Deus pra gente andar mais um tempo juntas, que é tão importante esse nosso grupo, mas o grupinho, além de ser grupo, colegas, vizinhas e pra mim é uma família. Nós somos que nem uma família, considero elas que nem uma família, pra mim nossa amizade vale tudo, é acima de tudo nossa amizade (...).

Vivian - Então tem um significado muito grande pra você!

Tereza - Tem. Por isso que o nosso bordado é tudo pra nós, é uma importância fora de série o bordado, e é uma tradição que vem dos avós, das mães, irmãs, então é uma pena, eu sempre falo, é 
uma pena parar por aqui, que ela disse que vai continuar, mas essas pessoas que tão aprendendo podem fazer uma coisinha pra casa, mas fazer um bordado assim pra vender...

Vivian - Você acha que não...

Tereza - Não ponho fé nisso, ninguém leva esse trabalho a sério, ninguém leva, borda assim pra passar o tempo, passatempo, mas dizer: "ah eu tô bordando assim porque eu aprendi, pra fazer jogo de lençol", não (...). Infelizmente tá acabando, eu falo: “mas é a realidade!”. Infelizmente tá acabando e quando essa turminha morrer, quem é que vai ter uma professora pra ensinar alguém? Não tem, não tem quem ensine, por isso que eu, às vezes, quando a gente pára assim pra refletir, eu fico pensando... Dona Paixão tá muito ruim, dona Maria também teve muito ruim da coluna, então, a gente fica muito ruim, eu fico preocupada com nosso grupinho sim, não vou dizer que não, que eu tô dizendo por dizer, é a realidade mesmo (...).

Tereza - Porque, para mim falar do bordado, pra mim é tudo. Pra mim é tudo. É uma coisa que vem, que tá no sangue, a gente vem com isso desde menina e quando a gente vê a mãe a gente já quer agulha mesmo e já fica bordando e então é muito importante. É muito importante pra mim, pra elas todas é a mesma coisa.

\section{“Mas tudo, tudo se faz. É só querer"}

Vivian - E como é dar aula?

Maria - Ah, é muito bom!

Vivian - É prazeroso?

Maria - Começou, começou em março as aulas!

Vivian - Março agora, deste ano [2006]?

Maria - Deste ano, começou as aulas, aí a gente, ih, mas foi mais de oitenta pessoas, muita gente, muita, de Cubatão, da Ponta da Praia ${ }^{19}$, de tudo quanto foi lado, apareceu inscrição de muita gente, se inscreveram tudo, mas quando viram que demorava, demora, né, um pouquinho...

Isabel - Sumiram!

Maria - ...foram desistindo, desistindo, hoje eu tô com sete, oito alunas, dona Isabel...

Isabel - Tava com seis, tô com três!

Maria - ...porque as aluninhas dela ficaram doentes, ficaram doentes...

Tereza - Eu tô com dez (...), mas eu adoro as minhas alunas. Nossa, é uma tarde tão agradável! (...) Nosso trabalho é muito difícil e elas começam a aprender e elas querem já fazer igual a gente, não conseguem e então elas ficam aborrecidas de às vezes, nem vão mais.

Maria - Mas este pouquinho que tem elas vão continuar, elas falam mesmo que vão continuar e tão gostando mesmo.

Tereza - As minhas dez continuam, o ano que vem...

Maria - No começo do ano...

Tereza - ...já tão bordando bem, fazendo caminho...

Maria - ...no começo do ano vai ter muita inscrição novamente...

Tereza - E a gente vê o bordado de uma, vê o bordado de outra, aí fala: "não é assim que a gente prenda”, aí vai lá e ensina, faz um pouquinho, entra com a agulha pra elas verem como entra sem ficar defeito... olha, realmente é difícil. Eu que sei bordar, mas pra quem começa, é o pior trabalho, é difícil, porque tem que ficar o ponto bem unidinho pra poder ficar o trabalho uma perfeição, eu falo pra elas,

19 Bairro da cidade de Santos. 
elas falam: "ai, eu quero bordar que nem a senhora", eu falo: "calma, vocês vão chegar!". Mas tem que continuar e eu já tenho esta idade e às vezes eu ainda aprendo alguma coisa, né, que tem um ponto novo, a gente às vezes até uma técnica a gente não imagina e às vezes a gente tá fazendo e vem à cabeça: "não, faça assim que é mais fácil". Nosso trabalho realmente é muito difícil, muito...

Maria - Mas tudo, tudo se faz. É só querer.

Tereza - ...quem aprender, quem tiver aprendendo...

Maria - ...tem que ter força de vontade...

Tereza - ...e quer continuar tem que ter muita força de vontade, tem que ser, que nem eu falo pra elas. E elas: "ah, eu sentei a bordar e não fiz nada!". Pro bordado render, pra ficar bom, precisa sentar num cantinho ali, sossegada...

Maria - É uma terapia!

\section{Ensinando...}

Maria - A gente vai na cidade e compra o tecido. Em casa a gente acerta o pano, puxa fio, acerta direitinho, risca, por exemplo, o desenho. Vamos desenhar, depois vamos desenhar, depois vamos bordar e quando tiver tudo bordado, a gente vai lavar, passar e a última coisa é recortar os biquinhos, pra depois embalar.

Vivian - Recortar estes fiozinhos que ficam soltos?

Maria - É, isso aqui, olha, isso aqui, ele não tá pronto ainda, ainda falta montar ele, botar forro, pôr o forrinho. Depois eu vou lavar, vou passar bem passadinho e engomar... e recorta e pra recortar é a última coisa... olha, recortar, tu quer ver o que que é? A gente faz assim, ó, tá vendo? Isso aqui é que chama recortar o caseado, tá vendo bem?

Vivian - Tô!

Maria - Tem que ser com muita atenção pra gente não cortar o bordado, ó, a gente apara aqui, depois de engomadinho não aparece nem um fiozinho, agora aparece porque não tá engomado, não tá passado, ó, mas fica assim, ó, tá vendo? Isto aqui é isto aqui, é o caseado recortado, é isso, tá vendo? Como eu estava falando, dá muito trabalho porque a gente tem que comprar o tecido, tem que riscar, bordar, depois lavar, engomar e passar no ferro e recortar e embalar no plástico, é assim.

Vivian - O que que é engomar?

Maria - É uma goma que a gente (...), a gente faz uma goma em casa, eu faço com maisena mesmo, pego um pouco de maisena com água, ponho no fogo, como quem vai fazer um mingauzinho, bem ralinho, aí molha e põe lá naquele mingauzinho e põe pra secar, depois passa no ferro, fica durinho, fica bem... este é um caminho de mesa (...).

Maria - Isso é cambraia, isso tinha uma camisa que não era cambraia, era de malha, mas eu achei que dava alergia no bebezinho, aí eu comprei cambraia, que é este tecido fininho, branquinho, aí eu comprei, eu bordei.

Paixão - Olha que bonito!

Maria - E pus assim, por dentro da... é que não dá alergia no bebê, bota um mijãozinho e a criança já está arrumadinha, é, já tá arrumadinha.

Vivian - E a sua especialidade é bebê?

Maria - É bebê, é bebê!

Vivian - A dela [dona Tereza] é lençol...

Maria - É, ela faz o lençol, ela faz lencinhos, caminho de mesa, paninho, bandeja...

Vivian - Cada uma faz uma coisa diferente... Isso aqui que é cambraia? 
Maria - É. Cambraia de linho, este babador é cambraia de linho agora cambraia é esta branquinha fininha, esta que é cambraia e que é pelinha de ovo, que chama que é de roupinha de bebê mesmo que não dá alergia, é antialérgico (...) e a virinha de manta, isso não se encontra mais.

\section{Bordado como fonte de renda}

Vivian - Vocês me falaram aquele dia [encontro anterior ao do dia da entrevista] que vocês não conseguiam sobreviver só com o bordado e que vocês trabalharam em outras coisas, em que outras coisas vocês trabalharam? Vocês são aposentadas em que?

Tereza - A gente era dona de casa e tinha um marido, então a gente nunca trabalhou fora.

Vivian - Então vocês têm aposentadoria dos maridos?

Tereza - Pensão.

Vivian - Então a aposentadoria que vocês falam é a pensão dos maridos?

Tereza - A aposentadoria que a gente fala é nossa mesmo, que a gente pagou pra se aposentar... nós pagamos como costureiras e então a gente tem a nossa aposentaria.

Isabel - Eu não paguei, se tivesse pagado estava numa boa!

Tereza - E temos ganhado um dinheirinho do bordado e então é um quebra-galho, né, então...

Isabel - Eu nunca trabalhei fora na minha vida! (...).

Tereza - Então, eu nunca trabalhei fora, porque a gente se acomoda, o marido fala uma coisa e a gente se acomoda e eu fiquei só no bordado, bordado, bordando, bordando, fazendo o trabalho de casa e bordando, bordando e, até hoje, e o tempo vai passando...

Isabel - Mas por que você nunca trabalhou fora?

Tereza - Porque o marido não deixou!

Isabel - O meu marido também não deixou (...).

Tereza - Essa época nenhum português deixava a mulher trabalhar fora, nenhum!

Isabel - Ignorância!

Tereza - (...) Então, a gente vai se acomodando. Só no bordado, só no bordado. Vai ganhando aquele pouquinho, mas é como se esse pouco, quando vê já é muito, e pra ganhar pouco, e ficar trabalhando fora só pra ficar escutando do marido, né, então a gente cuida das crianças (...) ...eu também nunca mais pensei em trabalhar fora, também nem quero, agora quero saber do bordado (...).

Maria - Como ajudava e ajuda até hoje, cada uma de nós tem a sua pensãozinha, né, a aposentadoria, é pouquinho, mas o pouquinho que a gente ganha é muito bom, muito bom, principalmente pra quem tem os seus remedinhos pra comprar. É, ajuda muito a gente.

Tereza - Aí eu sempre falo assim, quando a gente vende um bordado, eu sempre falo assim: "ai, obrigada Jesus, que dinheirinho abençoado!". Porque é do nosso trabalho, então parece que aquele dinheiro é mais valorizado, a nossa pensão, a nossa aposentaria a gente só vai no banco e já pega. Agora esse aqui a gente já tem o suor!

\section{“O trabalho de vocês é uma arte, muito, não tem quem faça igual”}

Vivian - Qual o significado que tem o bordado pra você? 
Tereza - Pra mim é tudo, é tudo na vida, parece que se eu parar de bordar, parece que eu me sinto assim inútil. Se eu ficar assim um dia: "ah, eu não vou bordar", aí fico, o corpo mole, parece que fico muito parada, então já tenho que começar a bordar. Agora, o ano que vem, eu tenho que parar um pouco, não sei, eu penso que vou fazer esporte, eu vou procurar fazer uns esportes, uma atividade, por causa do osso também, andar, que o médico mandou eu andar e eu não ando, eu até falei pra ele assim: "ah doutor, eu não tenho tempo de andar!", mas ele falou assim: "ah, mas a senhora anda de manhã", "mas de manhã é a hora que o bordado rende", aí ele ficou até parado. Aí ele nem teve resposta quando eu falei isso. Às vezes a gente fala as coisas... mas o ano que vem eu vou cuidar mais de mim.

Vivian - Mas não vai parar de bordar?

Tereza - Não vou mesmo, vou bordar menos, mas eu vou bordar, se Deus quiser. Enquanto eu puder eu quero bordar, a minha profissão, às vezes meu neto, o Maurício: "ai, vó, por que tu gosta tanto da tua, do bordar?", eu falo assim: "ai, Maurício, é a minha profissão e cada dia eu gosto mais". Engraçado, né, era pra gente enjoar, tem dias que a gente fala: "ai, enjoei desta, disso", mas do bordado cada vez eu gosto mais e escuto elas falarem também, a dona Maria: "cada vez eu gosto mais de bordar" e eu sou assim, cada vez eu gosto mais (...).

Vivian - Ah, mas você não é artista por bordar? Você acha que o seu bordado é uma arte?

Tereza - É uma arte, é uma arte. Meu trabalho é uma arte. Todo mundo fala assim: "o trabalho de vocês é uma arte, muito, não tem quem faça igual". O bordado da Ilha da Madeira não tem quem faça igual. Se você for assim no Ceará, tem aquele bordado feito a mão, não vou desfazer do bordado, que é bonito, mas como o da gente não tem em lugar nenhum. É o bordado mais famoso e tanto que estas pessoas que vão na Ilha da Madeira... que as pessoas ficam vendendo flores, eles vão buscar bordados, eles vão comprar toalhas de banquete, lençóis, bordados, eles vão lá comprar, eles encomendam, depois eles voltam buscar, Ilha da Madeira. Ilha da Madeira se fez no bordado, muito bordado assim pra exportar, muito, muito bordado, que os turistas, navios e navios iam lá buscar bordados na Ilha da Madeira. Mas a Ilha da Madeira ganhou muito bordado. Também era tradição, era tradição, a tradição do bordado era na Ilha, famosa. Tanto que quando a gente tava em São Paulo, quando a gente falava: "nós somos da Ilha da Madeira!", "ah, vocês são da Ilha da Madeira? O bordado mais famoso!", o pessoal quando viu Santos lá, as bordadeiras nós fomos tudo elogiadas lá, nossa, a gente ficava assim, foi muito elogio, nossa!

Maria - O significado do bordado pra mim é tudo. Adoro aquilo que eu faço, como já falei aprendi e eu gosto muito, é tudo isso. (...) É o que eu sei fazer e vou fazer enquanto eu enxergar, quando eu não enxergar, paciência (...) e vamos continuar para sempre, se Deus quiser, até quando Deus nos der vida, saúde e enxergar, né! Porque o importante de tudo é a gente enxergar, né, enquanto enxergar a gente vai indo (...).

Isabel - Ai, pra mim, é uma grandeza e também a gente não sabe fazer outra coisa. E pra mim vale tudo. Pra nós, minha filha, o tanto que a gente borda vale tudo e sempre dá um dinheirinho e hoje não vendi nada, mas sempre se vende alguma coisa (...).

Vivian - Vai dona Paixão, fala qual o significado do bordado pra você?

Paixão - Olha, pra mim ajudou muito mesmo: o marido ganhava pouco, aí eu comprava calçado para as crianças, ganhava dinheiro e pagava pra costureira, não é? E graças a Deus sempre tinha um pouco de dinheiro, nunca faltou um pão pra comer, não é? E trabalhar, e gostava tanto. E naquele tempo o bordado era barato, o dinheiro rendia; agora, pega cinqüenta reais não dá pra nada, mas não é? Pra mim ajudou muito, graças a Deus, aí eu tinha vontade de trabalhar, mas já que eu tô fazendo isso.

\section{"Não podemos esquecer a quem nos faz bem, a todos a gente agradece"}

Maria - A dona Beatriz foi uma grande lutadora por este grupo, muito, lutou muito por este grupo. Temos que nos lembrar sempre dela, temos que agradecer ao pessoal do Orquidário aqui, até, os 
funcionários, somos muito bem tratadas aqui, no Ilha Porchat Clube também. Dona Beatriz que se virou muito pra arrumar no começo.

Tereza - Aqui a gente deve muito à ex-prefeita Telma de Sousa ${ }^{20}$, que foi ela quem trouxe a gente pra cá e ela trouxe a gente e no tempo que ela era prefeita ela fazia uma barraquinha pra nós, com uma mesa pra cada bordadeira (...).

Maria - Mas olha, nós também, o Orquidário nunca deixou de nos aceitar, sempre estamos aqui, desde o começo delas até agora, por isso agradecemos muito à prefeitura de Santos, a todos os funcionários, não podemos esquecer a quem nos faz bem, a todos a gente agradece, até os próprios funcionários que nos tratam muito bem.

Tereza - A Tribuna também. A TV Tribuna ${ }^{21}$ todo mês leva a carta pra lá e o anúncio que eles põem não é grande, mas serve muito pra nós (...).

Maria - Nós vamos muito nas faculdades dar entrevista, com as meninas, para as meninas fazerem matérias. Nos colégios também chamam muito a gente e agradecemos muito também ao Teatro Municipal, que lá foi onde que a Secretaria (...) da Cultura de São Paulo ligou pra cá, pra cá pra Secretaria aqui de Santos, pra Casa da Cultura daqui de Santos, pra mandar as professoras que estavam dando aula de bordado da Ilha da Madeira pra São Paulo naquela exposição, foi nós três... (...) E como eu estava falando, a Secretaria nos convidou pra mandar as bordadeiras pra São Paulo, pra representar a cidade de Santos, nós fomos, nós três e o seu Messias ${ }^{22}$, tinha um estande lá pra gente expor o nosso trabalho, ficamos em São Paulo, que foi aquela festa que tem no Parque da Água Branca $^{23}$, em São Paulo, tem uma festa muito grande, tem muitas cidades...

Tereza - ...coisa tão bonita...

Maria - ...muitas cidades. Cada cidade representando, a pessoa representando sua cidade, aí nós ficamos, aí nós ficamos lá dez dias (...) ...e ficamos muito felizes, nós temos muito a agradecer à Prefeitura de Santos por ter nos convidado a ir pra São Paulo, porque foi uma experiência nova que nós tivemos; nunca nós saímos daqui de Santos para representar a nossa cidade de Santos em São Paulo. Ficamos muito orgulhosas, muito mesmo, foi uma pena de a nossa amiga não poder ter ido, a dona Paixão, porque ela muito doentinha não pôde, então, nós, como éramos as professoras que estávamos dando aula, fomos nós três, foi a Tereza, foi a dona Isabel e a Maria Alexandre, fomos nós três, mas foi muito bom demais, muito bom, ficamos dez dias num paraíso, parece que nós fomos pra Paris, de tão... lindo, que nós gostamos muito, demais, então tenho muito a agradecer a nossa Prefeitura de Santos, que nos mandou pra lá (...) ...e o Expresso Popular ${ }^{24}$ também, que foi dar uma entrevista lá na minha casa e aí começou a... sempre que nós precisamos, nós mandamos uma cartinha pra Tribuna e a Tribuna põe o anunciozinho e o Expresso Popular... temos muito a agradecer a eles sobre isso... daí que veio muita divulgação, daí o pessoal vem mais pra ver o nosso trabalho, não por causa de comprar muito, porque é um trabalho muito lindo, é um pouquinho mais caro, mas é lindo, é um trabalho maravilhoso, bordados feitos na Ilha da Madeira é um trabalho muito lindo e quando estamos aqui no Orquidário, vem muita gente pra ver, não que seja pra comprar, mas pra ver o trabalho e divulgar. Quer dizer que aí ficou muita divulgação, das faculdades, nos colégios, iam fazer matérias em, chamavam a gente pra entrevista e aí foi indo, foi indo, foi indo até agora e graças a Deus...

Tereza - ...graças à Tribuna, à TV Tribuna, que eles iam no morro fazer entrevista, filmando nossos trabalhos e depois passava na televisão...

Maria - E fizeram este livro maravilhoso, foi a Gisela. Temos que agradecer a ela também, ela é uma jornalista e ela fez este livro maravilhoso, que o meu está até na Prefeitura, lá, está lá na Prefeitura e

20 Telma de Sousa foi prefeita de Santos entre os anos de 1989 e 1992.

21 A TV Tribuna é afiliada ao Sistema Globo de Comunicações e detém os direitos de retransmissão na Baixada Santista e parte do Vale do Ribeira.

22 Seu Messias é um senhor que faz carrancas de madeira e expõe suas peças na praça dos Andradas, em Santos. Ele também participou da exposição no Festival do Parque da Água Branca.

23 "Revelando São Paulo - Festival da Cultura Paulista Tradicional”, festival que ocorre há dez anos no Parque da Água Branca, na cidade de São Paulo.

24 Outro jornal da região. 
cada uma de nós recebeu um livro, cada uma de nós. Não foi? Cada uma tem o seu livro. (...) Nós temos que agradecer a todos... é uma equipe... (...)

Tereza - Olha, em tudo lugar que a gente chegue, nós somos bem acolhidas...

Maria - ...graças a Deus!

Tereza - ...é uma amizade que a gente faz, que em tudo lugar que a gente chegue, nossa, é demais mesmo (...).

Maria - ...ele [Prefeito João Papa] ${ }^{25}$ comprou pra dar de presentinho. Ele veio aqui com a prefeita de uma, acho que era da França, é, uma prefeita da França veio visitar aqui o nosso prefeito em Santos, aí ele veio aqui no Orquidário e comprou uma linda orquídea pra ela de presente, aí passou aqui na nossa frente aonde nós estávamos com nosso trabalho, ele olhou e aquele, aquela prefeita de lá da França olhou pra banca, achou maravilhoso e aí ele comprou uma pecinha de cada uma da gente e deu de presentinho, ela adorou, ficou encantada, levou, esse foi nosso prefeito, João Papa. 